\title{
EFFECT OF SOIL CONDITIONERS ON SUBSURFACE DRIP IRRIGATION SYSTEM PERFORMANCE
}

\section{A.M. Abdel-Hameid"; M. S. Abuarab ${ }^{* *}$; M. M. Abdel-Wahap ${ }^{* * *}$;

\author{
W. M. Sultan ${ }^{* * * * *}$
}

\section{ABSTRACT}

The application of soil conditions is considered as a good management practices in any agricultural production system. The objectives of the present study was to evaluate the effect of organic and synthetic of soil conditions (compost, rice straw and polymers), on cucumber under subsurface trickle irrigation. A field experiments were carried out at ElHussien farm, Cairo-Alexandria road during the two summer seasons 2014 to 2015. The results showed that using compost with anti roots treatment $4 \mathrm{l} / \mathrm{h}$ achives higher yield and water use efficiency (WUE) $\mathrm{kg} / \mathrm{m}^{3}$ of cucumber grown in a sandy soil. For soil conditioners the yield was 2.12, 1.5 and 1.4 times greater, in the compost with antiroot treatment comparing with rice straw treatments, polymers treatments, and control treatments respectively. The WUE was $10.16 \%$ and $11.8 \%$ greater in the compost with anti root treatment comparing with compost with built in treatments and compost with $t$-tape, respectively, for the first season, while it was greater by $8.34 \%$ and $9.5 \%$ than compost with built in treatments and compost with t-tape, respectively, for the second season. Data from this study indicate that cucumber yield can be improved under SSDI if compost is used.

\section{INTRODUCTION}
Trigation method saving water is one of the key factors to save water and increase yield in the arid region. Drip irrigation is one of the irrigation methods saving water.

Drip irrigation system in general frequently irrigates crops, which can minimize water stress, increase crop yield and improve crops' quality (Hanson and May, 2004).

\footnotetext{
"Agriculture Engineer.

***Associate Professor of Agriculture Eng. - Faculty of Agric.- Cairo Univ.

**** Professor of Agriculture Eng. - Faculty of Agric.- Cairo Univ.

***** Senior Researcher in Agriculture Engineering Institute
} 
One of the most important developments of the drip irrigation system is the subsurface drip irrigation system (SSDI). This system is defined as the slow frequent application of water to the soil profile through drippers placed along a delivery line placed beneath the soil surface (Neufeld et al., 1999). Subsurface drip irrigation is considered to be the most modern irrigation system with efficient water delivery that can contribute immensely on improving crop water use efficiency and conserving water (Hanson and May, 2004). Soil Conditioner Types: There are various natural and synthetic materials used for soil reclamation. They are added to the soil surface or around the seedling roots at the time of planting, thereby improving the soil's physical properties. Natural organic matter includes Animal manure, crop residues, organic compost, sawdust, and various other materials such as food, textile, and paper processing wastes are used for soil reclamation to increase infiltration and retention, promote aggregation, provide substrate for biological activity, improve aeration, reduce soil strength, and resist compaction and crusting, and surface sealing. These are particularly important for improving the cropgrowing potential of sandy soils. The use of these materials for the purpose of soil improvement also contributes positively to solving the problem of waste materials disposal from the full range of human activities (Akelah, 2013). The best management practice for sandy soils is routine applications of organic matter. Organic matter holds 10 times or more water and nutrients than sand. Sandy soils with high organic matter content (4-5\%) make an ideal gardening soil. Soil organic matter helps to retain nutrients, maintain soil structure, and hold water for plant use. This important resource is subject to gain and loss (David et al., 2011). Straw is the major organic material source available to most rice farmers. Rice straw has long been considered an important source of nutrient because it contains about $0.6 \% \mathrm{~N}, 0.1 \%$ each of $\mathrm{P}$ and $\mathrm{S}, 1.5 \%$ $\mathrm{K}, 5 \% \mathrm{Si}$, and $40 \% \mathrm{C}$. Use of rice straw as mulching increased soil moisture accumulation, increased soil nutrients, enhanced soil bioactivity, increased plant growth and consequently increased plant production (Davies et al., 1993). The use of rice straw compost as an organic fertilizer, might be play a vital role not only in improving soil physical condition and water holding capacity but also in improving the plant nutrients (Esawy et al., 2009). Synthetic soil conditioner polymers 
such as Superabsorbent (SAP) can increase the water holding capacity of sandy soil (Al-Omran et al., 2004). El-Gindy et al., (2001) reported that sandy soil has low water holding capacity, so using soil conditioners especially polymers can increase the water holding capacity of the soil. Incorporated polymer into the soil will improve soil structure and water retention, thus reducing leaching, reducing water losses due to percolation and evaporation, protecting the plant against water stress and increasing both the nutrient and water supply to the roots.

The aim of this study is to improve yield and water use efficiency of cucumber by using soil conditioners (rice straw, compost and polymers) under subsurface Drip irrigation system.

\section{MATERIALS AND METHODS}

\section{Location and soil of experimental field plot:}

A field study was conducted from April to July 2014 and 2015 at ElHussein village (private farm), Cairo-Alexandria road, Egypt (latitude $30.15 \mathrm{~N}$, and $30.48 \mathrm{E}$ longitudes). Soil samples from surface down to 60 $\mathrm{cm}$ at $20 \mathrm{~cm}$ interval were collected. Hydrometer method was followed to determine the sand, silt and clay percentage of soil. The soil of the experimental area was deep, well-drained sandy (Table 1). Irrigation water was obtained from a deep well (60m depth from the soil surface) located in the experimental area, with $\mathrm{pH} 7.01$, and an average electrical conductivity of $7.06 \mathrm{dS} . \mathrm{m}^{-1}$.

Table 1. Physical and chemical properties of the experimental soil

\begin{tabular}{cccccc}
\hline Texture & $\begin{array}{c}\text { Field } \\
\text { capacity } \%\end{array}$ & $\begin{array}{c}\text { Wilting } \\
\text { point } \%\end{array}$ & $\begin{array}{c}\text { Bulk } \\
\text { density } \\
\left({\left.\mathrm{g} . \mathrm{cm}^{-3}\right)}^{-3}\right.\end{array}$ & $\mathrm{pH}$ & $\begin{array}{c}\mathrm{EC}_{\mathrm{e}} \\
\left(\mathrm{dS} . \mathrm{m}^{-1}\right)\end{array}$ \\
\hline Sand & 11.6 & 3.4 & 1.6 & 7.9 & 1.3 \\
Compost & 19.3 & 6.3 & 1.65 & 7.17 & 2.1 \\
Rice straw & 18.9 & 5.4 & 1.67 & 7.49 & 7.53 \\
polymers & 21.3 & 7 & 1.64 & 7.62 & 4.88 \\
\hline
\end{tabular}

2. System installation and experimental treatments:

A field plot of size $1296 \mathrm{~m}^{2}$ was selected for experimental studies. The field plot was divided into 36 equal plots of $2.4 \mathrm{~m} \times 15 \mathrm{~m}$. Each plot was including 3 rows $1 \mathrm{~m}$ apart, representing a single treatment. A layout of 
the experimental plots is shown in Fig. 1 the split plot design with 4 treatments subsurface Drip tapes (Built in $\left(\mathrm{I}_{1}\right)$; Anti-root $\left(\mathrm{I}_{2}\right)$; and T-tape $\left(\mathrm{I}_{3}\right)$ ), soil conditions (Compost $\left(\mathrm{S}_{1}\right)$; Rice straw $\left(\mathrm{S}_{2}\right)$; Polymer $\left(\mathrm{S}_{3}\right)$; and Control $\left(\mathrm{S}_{4}\right)$ ) and 3 replications of each treatment. Installation of the SDI system commenced in April 2014 with control facility, which control head unit is located at the source of water supply. It consists of centrifugal pump, pressure gauge, flow meter, back flow prevention device and screen filter, Main and sub-main lines $110 \mathrm{~mm}$ diameter, PVC pipes is used for the main to convey water from water source and $63 \mathrm{~mm}$ (P.V.C) for the sub-main., Manifold $32 \mathrm{~mm}$ (P.V.C) pipes is used to supply water to constructed laterals. Laterals lines of $16 \mathrm{~mm}$ diameter Polyethylene (PE), built in drip line with flow rate $4 \mathrm{l} / \mathrm{h}$. Cucumber seedlings (Cucmis sativus 1.) with three leaves were transplanted by hand in rows during April 2014 and 2015 under Subsurface Drip Irrigation system. The lines spacing were $0.8 \mathrm{~m}$, the line length was $15 \mathrm{~m}$, with 0.30 $\mathrm{m}$ emitters spacing. Using three types of soil conditions beneath the irrigation lines (Compost, Rice straw, and Polymers) at depth $0.20 \mathrm{~m}$.

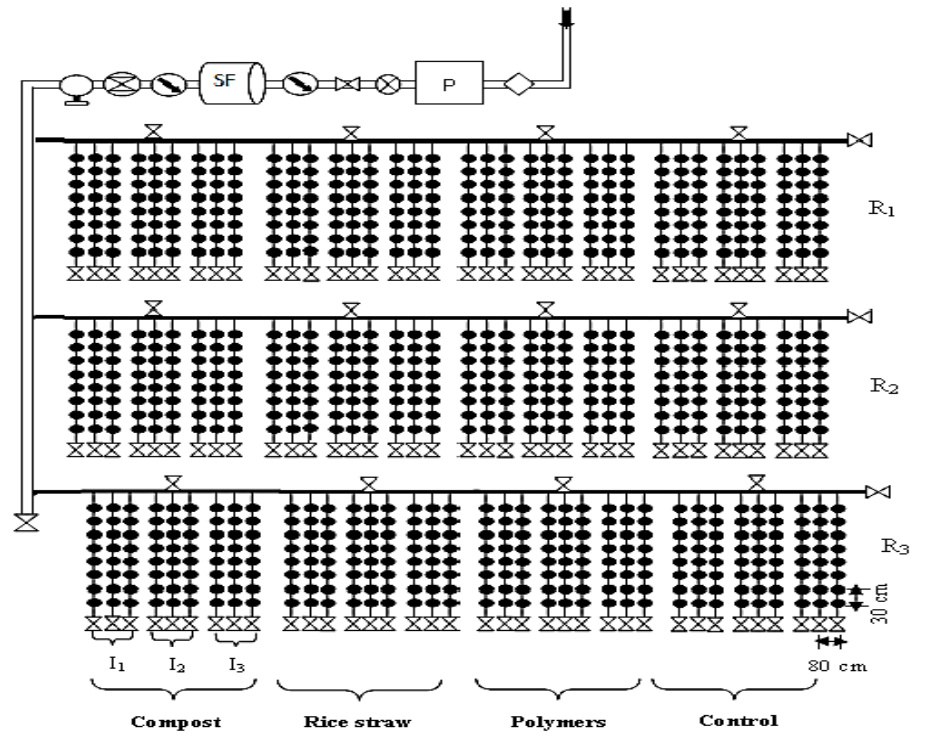

Fig. 1. Schematic hydraulic diagram of the micro irrigation system and treatments

\section{Estimation of uniformity of irrigation system:}

Hydraulic characteristics experiments were carried out the National Irrigation Laboratory of Agricultural Engineering Research Institute (AERI), Dokki, Giza for three types of built-in hoses (GR, GR Anti 
roots, and T-Tape).25drippers were selected randomly, the uniformity of water application was determined from the dripper outflow collected in cans for an estimated duration. The water application uniformity was calculated from the statistical distribution of dripper flow rates in terms of coefficient of variation ( $v$ ) and emission uniformity (EU) using equations (1) and (2) (Keller and Karmeli, 1975), as follows:

$$
\begin{aligned}
& \mathrm{CV}=\left(\mathrm{s} / \mathrm{q}_{\mathrm{a}}\right) \times 100 \\
& \mathrm{EU}=100\left(1.0-1.27 \frac{\mathrm{CV}}{\sqrt{\mathrm{N}^{\prime} \mathrm{p}}}\right)
\end{aligned}
$$

Where,

CV : manufacturer's coefficient of emitter variation,

$\mathrm{s}:$ : standard deviation of emitter flow rates at a reference pressure head,

$\mathrm{q}_{\mathrm{a}}:$ : Mean flow rate of emitter at that reference pressure head $(1 / \mathrm{h})$,

N'P : the number of emitters per plant, and

qn : The minimum discharge rate $(1 / h)$.

Five microirrigation uniformity classifications, ranging from excellent to unacceptable, recognized by the American Society of Agricultural Engineers (ASAE, $1996 \mathrm{a}, \mathrm{b}$ ) were used to evaluate SDI systems.

Table 2.Hydraulic characteristic of the trickle irrigation system

\begin{tabular}{llll}
\hline \multirow{2}{*}{ Characteristics } & \multicolumn{3}{c}{ Drip tapes } \\
\cline { 2 - 4 } & Built in & Anti-root & T-tape \\
\hline Wall thickness (mm) & 1 & 1.2 & 0.3 \\
Tape inner diameter (mm) & 16 & 16 & 16 \\
Pressure compensating & No & Yes & No \\
Dripper discharge (Lph) & 4 & 4 & 4 \\
Spacing between two drippers (cm) & 30 & 30 & 30.0 \\
Spacing between two tapes (cm) & 80 & 80 & 80 \\
Depth of placement of trickle tape & 15.0 & 15.0 & 15.0 \\
(cm) & 0.5 & 0.5 & 0.5 \\
Exponent (x) & 1.49 & 3.15 & 2.96 \\
CV & 97.1 & 98.8 & 96 \\
EU & & & \\
\hline
\end{tabular}

\section{Nutrient management:}

Fertilizers were uniformly applied for all treatments, the base fertilizer applications were $60 \mathrm{t} \mathrm{ha}^{-1}$ chicken dung and 120 for $\mathrm{N}$ (as urea with $46 \% \mathrm{~N}), 180 \mathrm{P}\left(\mathrm{P}_{2} \mathrm{O}_{5}\right)$, and $150 \mathrm{~kg} \mathrm{ha}^{-1} \mathrm{~K}\left(\mathrm{~K}_{2} \mathrm{O}\right)$, and $300 \mathrm{~kg} \mathrm{ha}^{-1} \mathrm{~N}$ were injected through subsurface drip irrigation system for four times equally during fruiting period (Wang et al., 2009). 


\section{Data recording:}

At the day of final harvest on 30 July (105 days after planting (DAP)),18 plants were harvested from each plot by taking six plants from each of the beginning, middle and end of the plot respectively, for yield mass determination. Total fresh weight of the fruits was determined $(\mathrm{kg}$ per plant).The vegetative parameters were plant height, number of branches, number of leaves per plant, fruit diameter, fruit length, fruit weight and fresh weight per plant was derived from final plant harvest. Actual evapotranspiration within the growing period was estimated from the soil water balance from the following equation:

$$
E T_{C}=E T_{0} * K_{C}
$$

Where:

ETC : Crop consumption use (mm/day).

ETO : Reference evapotranspiration ( $\mathrm{mm} /$ day).

Kc : Crop coefficient (dimension less).

ETo is calculated using the weather data as input to the PenmanMonteith equation and the Kc is used to adjust the estimated ETo for the reference crop to that of other crops at different growth stages and growing environments.

\section{.6. Water-use efficiency:}

Water-use efficiency (WUE) and irrigation water-use efficiency (IWUE) values were calculated with Eqs. (4) and (5), respectively (Ertek et al., 2006).

$$
\begin{aligned}
& \text { WUE }=\left(\frac{Y}{E T_{\mathrm{o}}}\right) \times 100 \\
& \text { MWUE }=\left(\frac{Y}{I_{\mathrm{r}}}\right) \times 100
\end{aligned}
$$

Where

WUE : water use efficiency $\left(\mathrm{t} \mathrm{ha}^{-1} \mathrm{~m}^{-3}\right)$

Y : economical yield $\left(\mathrm{t} \mathrm{ha}^{-1}\right)$;

IWUE : Irrigation water use efficiency $\left(\mathrm{t} \mathrm{ha}^{-1} \mathrm{~m}^{-3}\right)$

Ir $\quad: \quad$ the amount of irrigation water applied $\left(\mathrm{m}^{3}\right)$

\section{Evapotranspiration:}

\section{RESULTS AND DISCUSSION}

The results in the (Table 3) indicated that there was no significant difference in irrigation water applied and evapotranspiration between soil 
conditioners, buit in, and the interaction between them for both grown seasons. There was a $0.23 \%, 0.6 \%$ and $1.8 \%$ decrease in irrigation water applied (I) of cucumber, of compost treatment $\left(\mathrm{S}_{1}\right)$ comparing with rice straw treatments $\left(\mathrm{S}_{2}\right)$, polymers treatments $\left(\mathrm{S}_{3}\right)$ and control treatments $\left(\mathrm{S}_{4}\right)$, respectively, for the first season, while it was lower by $0.23 \%, 0.57 \%$ and $1.72 \%$ than $S_{2}, S_{3}$, and $S_{4}$ respectively, for the second season. While the water use (ET) was $0.27 \%, 0.67 \%$ and $4.4 \%$ lower, in compost treatment than with rice straw treatments, polymers treatments and control treatments, respectively, for the first season, while it was lower by $0.38 \%, 0.94 \%$, and $4.77 \%$ than $\mathrm{S}_{2}, \mathrm{~S}_{3}$ and $\mathrm{S}_{4}$ treatments respectively, for the second season.

Table 3.Total irrigation water amount (I), plant water consumption (ET), yield, irrigation water use efficiency (IWUE) and water use efficiency (WUE) of cucumber for the growing season and irrigation treatments.

\begin{tabular}{|c|c|c|c|c|c|c|}
\hline $\begin{array}{l}\text { Main } \\
\text { plot }\end{array}$ & Sub main plot & $\begin{array}{l}\text { I } \\
\mathbf{m}^{3} h^{-1}\end{array}$ & $\begin{array}{l}\text { ET } \\
\mathbf{m}^{3} h^{-1}\end{array}$ & $\begin{array}{l}\text { Yield } \\
\left(t h^{-1}\right)\end{array}$ & $\begin{array}{l}\text { IWUE } \\
\left(\mathrm{kg} \mathrm{m}^{-3}\right)\end{array}$ & $\begin{array}{l}\text { WUE } \\
\left(\mathrm{kg} \mathrm{m}^{-3}\right)\end{array}$ \\
\hline \multirow{3}{*}{ Compost } & Built in com & 3492 & 4093 & $27.22 b$ & $7.795 b$ & $6.65 b$ \\
\hline & Anti root com & 3492 & 4093 & $30.33 a$ & $8.686 \mathrm{a}$ & $7.41 \mathrm{a}$ \\
\hline & T-tape com & 3492 & 4093 & $25.92 \mathrm{c}$ & $7.423 \mathrm{c}$ & $6.333 c$ \\
\hline \multirow{3}{*}{$\begin{array}{l}\text { Rice } \\
\text { straw }\end{array}$} & Built in rice & 3500 & 4104 & $19.57 \mathrm{e}$ & $5.591 d$ & $4.769 \mathrm{e}$ \\
\hline & Anti root rice & 3500 & 4104 & $20.16 d$ & $5.76 \mathrm{~d}$ & $4.912 \mathrm{~d}$ \\
\hline & $\mathrm{T}$-tape rice & 3500 & 4104 & $19.35 \mathrm{e}$ & $5.529 \mathrm{de}$ & $4.715 \mathrm{e}$ \\
\hline \multirow{3}{*}{ Polymers } & Built in pol & 3513 & 4120 & $18.46 \mathrm{~h}$ & $5.255 \mathrm{ef}$ & $4.481 \mathrm{f}$ \\
\hline & Anti root pol & 3513 & 4120 & $18.27 \mathrm{f}$ & $5.201 \mathrm{f}$ & $4.434 \mathrm{f}$ \\
\hline & T-tape pol & 3513 & 4120 & $16.57 \mathrm{~g}$ & $4.717 \mathrm{~g}$ & $4.022 \mathrm{~g}$ \\
\hline \multirow{4}{*}{ control } & Built in con & 3557 & 4283 & $13.4 \mathrm{f}$ & $3.767 \mathrm{~h}$ & $3.129 \mathrm{i}$ \\
\hline & Anti root con & 3557 & 4283 & $13.85 \mathrm{~h}$ & $3.894 \mathrm{~h}$ & $3.234 \mathrm{~h}$ \\
\hline & T-tape con & 3557 & 4283 & $11.62 \mathrm{i}$ & $3.267 \mathrm{~h}$ & $2.713 \mathrm{j}$ \\
\hline & LSD & NS & NS & 0.5 & 0.29 & 0.08 \\
\hline
\end{tabular}

\section{Yield and Water use efficiency:}

The characteristics of yield and water use showed a significant differences between soil conditioners (copmpst, rice straw, and polymers), and buit in (GR, Antiroot, and T-tape) for two growing seasons and the interaction between them. For drip tape the yield was $4.8 \%$ and $9.8 \%$ greater, in the built in (anti roots) treatment $\left(\mathrm{I}_{2}\right)$ comparing with built in (GR) treatments $\left(\mathrm{I}_{1}\right)$ and built in (t-tape) treatment $\left(\mathrm{I}_{2}\right)$. For soil conditioners the yield was 2.1, 1.5 and 1.4 times greater, in the compost treatment $\left(\mathrm{S}_{1}\right)$, rice straw treatments $\left(\mathrm{S}_{2}\right)$, polymers treatments $\left(\mathrm{S}_{3}\right)$, comparing with control treatments $\left(\mathrm{S}_{4}\right)$ 
respectively (Table 2). The results showed that the highest yield was (30.3 $\mathrm{t} \mathrm{h}^{-1}$ ) for compost with built in (anti roots) treatment and the lowest value was $\left(11.6 \mathrm{t} \mathrm{h}^{-1}\right)$ for control with built in (T-tape) treatment Fig. (2).

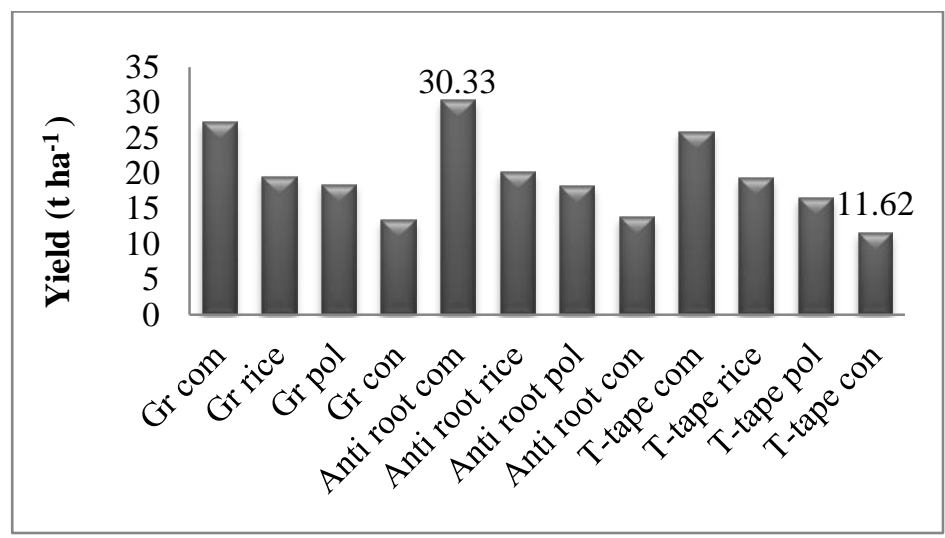

Fig. (2) Effect of soil conditioners and lateral drip types on cucumber yield.

The results agree with (Roe et al., 1997) studied cucumbers in a sandy soil fertilized with compost or mineral fertilizers. And they found that, yields were usually higher when compost was combined with mineral fertilizers. The increase in total produced yield, might be due to the function of the increase vegetative growth and dry matter contents of the plant and turn to the increase first number one average fruit weight. Similar findings were obtained by (Eid et al., 1987). Melero et al., (2007) studied the effects of organic fertilization on chemical and biochemical properties of a Mediterranean soil under dry land agriculture and found that compost-amended soils exhibited increases in quantity and quality of total organic carbon, nitrogen, phosphorus, microbial biomass, and enzymatic activities. The control treatment had the least values of soil nutrients, growth and yield parameters of cucumber when compared to other treatments and this could be due to continuous growing of crops on the same piece of land which led to soil nutrients depletion and the resultant low soil fertility status. This finding was also supported by Ojeniyi and Moyin-Jesu (2006).

Water use efficiency considered indicator to yield and irrigation water applied, the result showed that the greatest values of WUE was $(8.7 \mathrm{~kg}$ 
$\mathrm{m}^{-3}$ ) compost with built in (anti roots) treatment with highest yield and lowest value of irrigation water. But the lowest value of WUE was (3.3 $\mathrm{kg} \mathrm{m}^{-3}$ ) for control with built in (T-tape) treatment. In this respect, Ali et al., (2006) also found that the application of compost for tomatoes increased water use efficiency, this could be due to the role of rice straw compost as organic fertilizer on better holding the water in the root zone. The control treatment had the least values of soil nutrients, growth and yield parameters of cucumber when compared to other treatments and this could be due to continuous growing of crops on the same piece of land which led to soil nutrients depletion and the resultant low soil fertility status. The result was also supported by Moyin-Jesu and Ojeniyi (2006).

Most polymeric superabsorbents are based on sodium polyacrylate, but they are not suitable for saline water and soils (Akelah, 2013).

\section{Vegetative growth parameters:}

The plant height is not a yield component in vegetables but it indicates the influence of various nutrients on plant metabolism. For both season, there was a significant difference in plant height between lateral drip types, soil conditioners, and the interactions between them. The highest values of plant height was $(166.3 \mathrm{~cm})$ under compost with anti-roots treatment, while the lowest values was $(102 \mathrm{~cm})$ under control with built in. While the highest values of leaves areas $\left(196 \mathrm{~cm}^{2}\right)$, and the lowest values of leaves areas $\left(107 \mathrm{~cm}^{2}\right)$ for compost with built in and control with T-tape treatments, respectively. The results showed that, there was significant difference in fruit diameter between soil conditioners, but there was no significant difference between lateral drip tapes, the interactions between lateral drip tapes and soil conditioners for both grown seasons, The interaction between the lateral drip tapes and soil conditioners, the highest values of Fruit diameter $(3.1 \mathrm{~cm})$, and the lowest values of leaves areas $(2.34 \mathrm{~cm})$ for compost with GR anti-roots and polymer with T-tape treatments, respectively.

\section{CONCLUSION}

The utilization of soil conditioners in this study aimed to improve its effects on yield, quality components and water use efficiency (WUE) of cucumber grown in sandy soil. An important conclusion is that: 
1) The application of compost with built in types achieve higher yield, WUE and made an improvement under salinity, especially with GR anti-roots.

2) Generally, all soil conditioners had more or less positive influence on the soil physicochemical characteristics and on cucumber plants. When compost was added to the soil, all plant growth characteristics were improved.

3) There are no difference between any built in types under soil conditions (Built in, GR anti roots, and T-tape) on yield and plant growth and water use efficiency.

\section{REFERENCES}

Akelah A. 2013. Functionalized polymeric Materials in Agriculture and the food Industry. Xlv, 367 p. 112 illus., 21 illus. in color., Hardcover ISBN:978-1- 4614-7060-1

Ali, H.I.,Ismail, M.R.,Manan, M.M., Saudi, H.M. 2006. Rice straw compost and water deficit affect yield, quality and water use efficiency (WUE) of tomatoes grown in different media. Biol Agric. Hortic., 24: 301- 316.

Al-Omrana, A. M., Shetaa, A. S., Falataha, A. M., Al-Harbib, A. R. 2004. Effect of drip irrigation on squash (Cucurbita pepo) yield and water use efficiency in sandy calcareous soils amended with clay deposits.

ASAE. 1996a. Field Evaluation of Micro Irrigation Systems. EP405.1. ASAE Standards. Amer. Soc. Agric. Engr., St. Joseph, MI, pp. 756-759.

ASAE. 1996b. Design and Installation of Micro Irrigation Systems. EP409. ASAE Standards. Amer. Soc. Agric. Engr., St. Joseph, MI, pp. 792-797.

David, W., Adrian, C., Carl, W. 2011. Managing Soil Tilth Texture, Structure and Pore Space.PhD. Colorado State University Extension.

Davies, D. H. K., Drysdale, A., McKinlay, R. J., Dent, J. B., Williams, G. H.1993. Novel approaches to mulches for weed control in 
vegetables, Proc. of a Conf. on Crop Protection in North. Britain, Dundee 23-25 March, pp: 271-276.

Esawy, M.; M. Ibrahim; P. Robin; N. Akkal-Corfini and M. El-Saka (2009). Rice straw composting and its effect on soil properties. Compost Sci. Utilization, 17 (3): 146-150.

Eid, H.M., Ainer, N.G.,Metwally, M.A. 1987. Estimation of irrigation and temperature needs for the new pods in Egypt Conf. of Agric. Sci on food Deficiency Overcoming Through Autonomous Efforts in Egypt, Mannsoura Univ. pp. 907-914.

El-Gindy, A. M., Abdel-Mageed, H. N., El-Adl, M. A., Mohamed, E. M. K. 2001. Management of pressurize irrigated faba bean in sandy soil. Misr J. Ag. Eng., Vol.18 (1): 29-44.

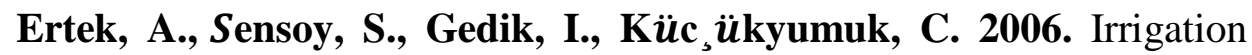
scheduling based on pan evaporation values for cucumber (Cucumis sativus L.) grown under field conditions. Agric. Water Manage. 81, 159-172.

Hanson, B., May, D., 2004. Effect of subsurface drip irrigation on processing tomato yield, water table depth, soil salinity, and profitability.Agriculture Water Management. 68, 1-17.

Keller, J. and Karmeli, D. 1975. Trickle irrigation design. Rain Bird Sprinkler Manufacturing Corporation, Glendora, CA, 133p.

Moyin-Jesu, E.I., Ojeniyi, S.O. 2006. Effects of sole and amended plant residues on soil nutrient contents and yield of Okra (Abelimoschusesculentum L).Discovery and Innovation Journal. 18(4): 318-326.

Melero, S., Madejon, E., Ruiz, J. C. and Herencia, J. F. 2007. Chemical and biochemical properties of a clay soil under dryland agriculture system as affected by organic fertilization. Eur. J. Agron. 26: 327-334.

Neufeld, J., J. Davison, and T. Stevenson, 1999. Subsurface drip irrigation, Nevada cooperative extension, Fact Sheet 97-13, University of Nevada, Reno URL: http://www.unce.unr.edu/publications/FS97/FS9713.pdf. 
Roe, N.., Stoffella, P.J., Graetz, D. 1997. Composts from various municipal solid waste feed stocks affected vegetable crops. 2: Growth, yields and fruit quality. J. Amer. Soc. Hort. Sci., 122: 433437.

Wang, Z., Liu, Z., Zhang, Z., Liu, X. 2009. Subsurface drip irrigation scheduling for cucumber (Cucumis sativus L.) grown in solar greenhouse based on $20 \mathrm{~cm}$ standard pan evaporation in Northeast China. Scientia Horticulturae 123 51-57

الملخص العربحى

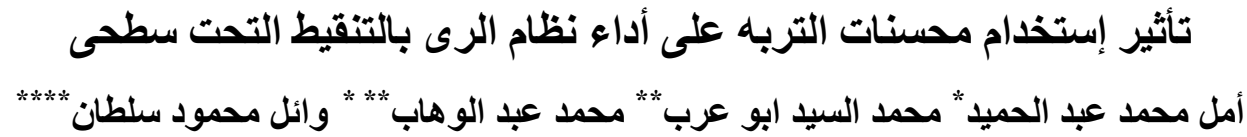

يعتبر اضافة محسنات التربة باعتبار ها ممارسات الإدارة الجيدة في أي نظام الإنتاج الزر اعي لأنه يحسن من نمو وانتاجية النبات وخصوبة التربة. لذلك كان الهدف من الدر اسة هو تحسين انتاجيه وكفاءة استخدام

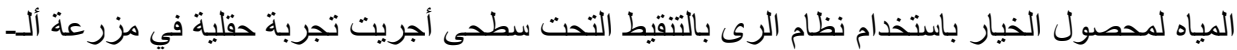

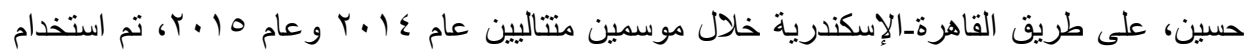
ثلاثة انو اع من خر اطيم الرى بالتقفيط ذات منقطات داخليه (GR, GR anti roots, T-tape)، وثنلاثه

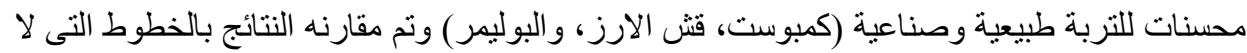

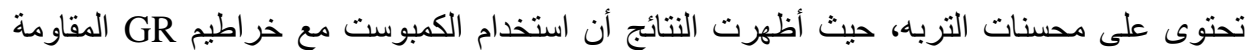
لاختر اق الجذور أعطى أعلي إنتاجية وأعلى كفاءة لأستخدام المياه ( WUE) مقارنة مع بقية المعاملات.

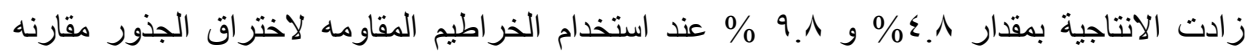

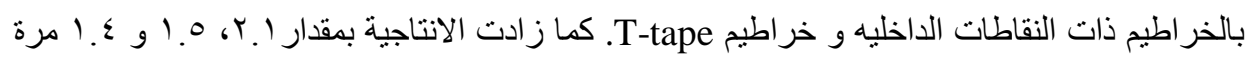

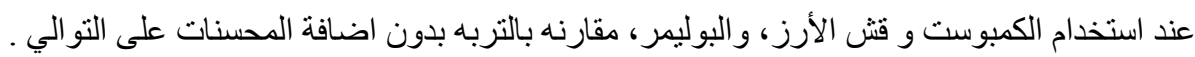

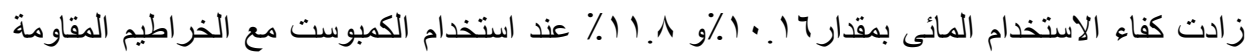

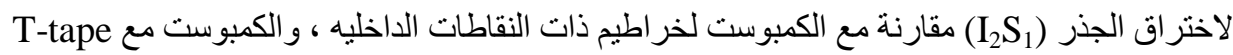

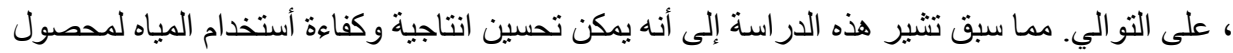
الخيار المزروع فى التربه الرمليه تحت نظام الرى بالتتقيط التحت سطحى باستخدام الكمبوست مقارنة بقش الأرز و البوليمر و التربة العادية بدون أستخدام المحسنات. وذلك لان الكمبوست يمد النبات بالمو اد الغذائية اللازمه للنمو ويعمل على تحسين الانتاجيه كما انه يعمل لإنل

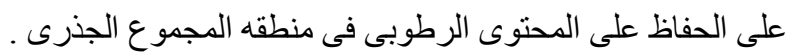

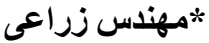

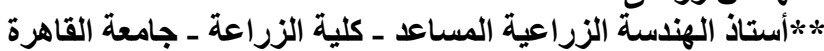

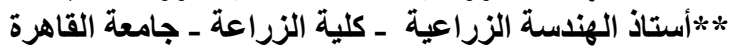

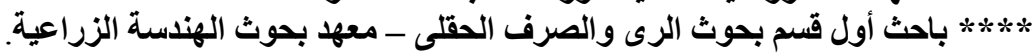

